\title{
Estrogens and Antiestrogens Stimulate Release of Bone Resorbing Activity by Cultured Human Breast Cancer Cells
}

\author{
Alexandre Valentin-Opran, Gabriel Eilon, Simone Saez, and Gregory R. Mundy \\ Laboratoire de Biologie Medicale Centre L. Berard, 69008 Lyon, France; Department of Medicine, University of Connecticut \\ Health Center, Farmington, Connecticut 06032; and Department of Medicine/Endocrinology, University of Texas \\ Health Science Center at San Antonio, Texas 78284
}

\begin{abstract}
Patients with advanced breast cancer may develop acute, severe hypercalcemia when treated with estrogens or antiestrogens. In this study, we examined the effects of estrogens and related compounds on the release of bone resorbing activity by cultured human breast cancer cells in vitro. We found that the estrogen receptor positive breast cancer cell line MCF-7 releases bone resorbing activity in response to low concentrations of $17 \beta$ estradiol. Bone resorbing activity was also released in response to the antiestrogen nafoxidine. Other steroidal compounds had no effect on the release of bone resorbing activity. Estrogenstimulated release of bone resorbing activity occurred with live bone cultures, but not with devitalized bones, indicating that the effect was bone cell mediated. The breast cancer cell line MDA-231, which does not have estrogen receptors, did not release bone resorbing activity in responise to $17 \beta$-estradiol or nafoxidine. Release of the bone resorbing activity by MCF-7 cells incubated with $17 \beta$-estradiol was inhibited by indomethacin $(10 \mu \mathrm{M})$ and flufenamic acid $(50 \mu \mathrm{M})$, two structurally unrelated compounds that inhibit prostaglandin synthesis. Concentrations of $17 \beta$-estradiol and nafoxidine that caused increased release of bone resorbing activity by the breast cancer cells caused a four- to fivefold increase in release of prostaglandins of the $E$ series by MCF-7 cells. These data may explain why some patients with advanced breast cancer develop acute hypercalcemia when treated with estrogens or antiestrogens, and why bone metastases are more common in patients with estrogen receptor positive tumors.
\end{abstract}

\section{Introduction}

Breast cancer, the most common malignancy in women, frequently involves the skeleton (1). Metastatic bone lesions may be osteolytic or osteosclerotic. They frequently lead to intractable pain, fractures, and occasionally hypercalcemia. Approximately $90 \%$ of women dying with breast cancer have bone metastases (2-4), and $>30 \%$ develop hypercalcemia (5). Once tumor cells involve bone, only palliative treatment with hormonal therapy (such as estrogens, antiestrogens, or androgens) or chemotherapy is possible.

Address reprint requests to Dr. Mundy.

Received for publication 13 December 1983 and in revised form 20 September 1984.

J. Clin. Invest.

(C) The American Society for Clinical Investigation, Inc.

0021-9738/85/02/0726/06 \$1.00

Volume 75, February 1985, 726-731
To develop more effective forms of therapy for breast cancer that has metastasized to bone, we need to understand the mechanisms by which breast cancer cells influence bone cell metabolism. The most important abnormality appears to be an increase in bone resorption with resultant lytic metastases and often hypercalcemia (1). The mechanism by which bone resorption is increased in breast cancer is unknown, although a number of studies have implicated prostaglandins (6-9), which increase the activity of osteoclasts, the major bone resorbing cells. It has also been shown that breast cancer cells can directly resorb bone in vitro by the production of hydrolytic enzymes $(10,11)$.

Steroid hormones clearly influence breast cancer cell growth. Many tumors have steroid hormone receptors $(12,13)$, and some tumors will respond to hormonal manipulations, including the administration of estrogens, antiestrogens, or androgens (14). It has been known for $40 \mathrm{yr}$ that administration of estrogens or antiestrogens may lead to the precipitation of acute and severe hypercalcemia (15-18), even when tumor growth regresses in response to the hormone $(18,19) .15 \%$ of estrogen receptor positive women treated with estrogens develop acute severe hypercalcemia (16), and $\sim 2 \%$ of women with advanced breast cancer develop acute hypercalcemia when treated with antiestrogens such as nafoxidine or tamoxifen (20). The mechanism of hormone-stimulated hypercalcemia in breast cancer is unknown.

In this study, we examined the effects of estrogens and antiestrogens on the production of bone resorbing activity by cultured human breast cancer cell lines in vitro. We found that $17 \beta$-estradiol and nafoxidine caused increased release of bone resorbing activity by cultured human breast cancer cells with estrogen receptors. This effect was inhibited by drugs that block prostaglandin synthesis. The production of bone resorbing activity by the breast cancer cells corresponded to their increased release of prostaglandins of the $\mathrm{E}$ series.

\section{Methods}

The experiments described in this report were performed in two separate laboratories, one in Farmington, Connecticut, the other in Lyon, France. In one laboratory (Farmington, Connecticut), bone resorbing activity was assessed using conditioned media harvested from cultured MCF-7 cells incubated with fetal rat long bones in organ culture. In the other laboratory (Lyon, France) bone resorbing activity from MCF-7 cells was assessed by co-culture of MCF-7 cells with neonatal mouse calvaria in organ culture.

\section{Bone resorbing assays}

Fetal rat long bone assays. These assays were performed in Connecticut. The method for assessing bone resorbing activity has been described in detail previously $(21,22)$. Bones were obtained from the fetuses of pregnant rats on the 19th $d$ of gestation. On the 18th $d$ the rats were given a subcutaneous injection of $0.05 \mathrm{mCi}$ of ${ }^{45} \mathrm{Ca}$. The radius and 
ulna were explanted from the fetus and placed in organ culture for 72 $h$. The first 24-h period was a preculture period to allow for exchange of loosely complexed ${ }^{45} \mathrm{Ca}$ with stable calcium in the control media. Conditioned media harvested from MCF-7 or MDA-231 cultured human breast cancer cells were incubated with the bones over the following 48-h period.

Both of these tumor cell lines were derived originally from malignant pleural effusions from two different patients with disseminated breast cancer $(23,24)$. Our cells were obtained from E.G. and G. Mason Research Institute, Rockville, MD. Cell culture media used in these experiments was harvested from cultures that were near confluency. The MCF-7 cells were cultured in Dulbecco's modified Eagle's medium (Gibco Laboratories, Grand Island, NY) with $10 \%$ fetal calf serum (Gibco). The MDA-231 cells were grown in L15 medium (Gibco) with similar amounts of fetal calf serum. The fetal calf serum was stripped by exposure to charcoal to remove steroid hormones. The cells were grown to confluency and cultures routinely split every week. In some experiments the cultures were incubated for varying periods with steroid hormones (24-96 h). Harvested cell culture media were centrifuged for $10 \mathrm{~min}$ at $1,000 \mathrm{~g}$. The cell-free supernates were then adjusted to $\mathrm{pH} 7.4$ with $1 \mathrm{M} \mathrm{NaHCO}$ and sterilized by passage through filters (pore size, $0.22 \mu \mathrm{m}$; Millipore Continental Water Systems, Bedford, MA).

In those experiments in which inhibitors of prostaglandin synthesis were used, indomethacin $(10 \mu \mathrm{M})$ and flufenamic acid $(50 \mu \mathrm{M})$ were given simultaneously with the steroid compounds. Bone resorbing activity was calculated as the percent of total radioactivity released into the medium during the period of culture, and differences were analyzed using $t$ test for nonpaired samples.

Neonatal mouse calvaria assays. These assays were performed in Lyon and used co-culture of tumor cells with the bone cultures. The mouse calvaria bone resorption assay is similar to that described by Reynolds (25). $48 \mathrm{~h}$ before parturition pregnant mice were injected subcutaneously with $0.05 \mathrm{mCi}$ of ${ }^{45} \mathrm{Ca}$ (Commissariat à l'Energie Atomique, Saclay, France) $(9.9 \mathrm{mCi} / \mathrm{mg} \mathrm{sp}$ act $) .7-9 \mathrm{~d}$ after birth, the calvaria of the neonatal mice were explanted and cultured in BGJ-b medium (Gibco). Live explanted half calvarias were cultured for $24 \mathrm{~h}$ in control BGJ-b medium at $37^{\circ} \mathrm{C}$ and $5 \% \mathrm{CO}_{2}$ to remove loosely bound ${ }^{45} \mathrm{Ca}$. The breast cancer cells were plated $72-96 \mathrm{~h}$ before the onset of culture, with the bones in six well culture dishes, and were, therefore, near confluency by the time the bone culture was to begin. $1 \mathrm{ml}$ of medium was used in the co-culture system and $5 \times 10^{4}$ cells/ $\mathrm{ml}$ were placed at the beginning of the culture. The bones were placed on grids at the air-medium interface. One-half of each calvaria was introduced into wells containing breast cancer cells while the other half served as a control and was cultured with corresponding control medium. The MCF-7 cells were cultured in Ham's F-17 medium (Gibco) with $10 \%$ fetal calf serum (Gibco). In these experiments, the fetal calf serum was not charcoal stripped. Fresh medium was added to each well after each 48-h period. Hormones were added in some wells at the onset of the co-culture, or 72 or $96 \mathrm{~h}$ before the onset of co-culture. The duration of the co-cultures was $96 \mathrm{~h}$. At the end of the co-culture period the bones were hydrolyzed in $\mathrm{HCl}$. Bone resorption was assessed by taking the ratio of ${ }^{45} \mathrm{Ca}$ released into the medium from the half calvaria incubated with MCF-7 cells and hormones to the ${ }^{45} \mathrm{Ca}$ released from paired half-calvaria treated in exactly the same way, except that cells were not added. Experiments were repeated 2-7 times using 5-15 paired bones per experiment. Differences were analyzed using $t$ test for paired samples.

In some experiments, devitalized calvaria were used. The bones were devitalized by exposure to UV light while immersed in distilled water at room temperature for $24 \mathrm{~h}$.

\section{Prostaglandin $E$ radioimmunoassay}

Prostaglandins were determined in the supernatant media of the MCF-7 cultures by radioimmunoassay, using a specific antibody to prostaglandin $\mathrm{E}_{2}\left(\mathrm{PGE}_{2}\right)^{\prime}$ (Boehringer Mannheim Biochemicals, Indi-

1. Abbreviation used in this paper: $\mathrm{PGE}_{2}$, prostaglandin $\mathrm{E}_{2}$. anapolis, IN) and the IgG sorb technique. This assay has $20 \%$ crossreactivity with prostaglandin $E_{1}$. Prostaglandins were assayed in the cell culture supernatants $6 \mathrm{~h}$ after exposure of the tumor cells to the steroid compounds. After addition of ${ }^{3} \mathrm{H}-\mathrm{PGE}_{2}$ (New England Nuclear, Boston, MA) for calculation of recovery, the culture supernates were extracted twice with 2:1 ethylacetate/cyclohexane, and the extracts were dried under nitrogen and then reconstituted with $0.2 \mathrm{M}$ phosphate buffer ( $\mathrm{pH} 7.9$ ) containing $1 \%$ rabbit serum. Using this method, $\sim 70 \%$ of the $\mathrm{PGE}_{2}$ is recoverable.

\section{Cell protein}

The total protein content of cultured tumor cells per well was measured in cell sonicates using the technique of Lowry et al. (26).

\section{Cell DNA content}

DNA content of the cultured tumor cells was determined using the ethidium bromide technique of Karsten and Wollenberger (27).

\section{Chemicals}

$17 \beta$-estradiol, $17 \alpha$-estradiol, dihydrotestosterone, indomethacin, and flufenamic acid were all of reagent grade and were purchased from the Sigma Chemical Co., St. Louis, MO. ${ }^{45} \mathrm{Ca}$ was purchased from New England Nuclear. Nafoxidine was kindly provided by The Upjohn Co., Kalamazoo, MI.

\section{Results}

Fig. 1 shows the effects of $17 \beta$-estradiol and $17 \alpha$-estradiol on the release of bone resorbing activity from MCF-7 cells using the fetal rat long bone system. MCF-7 cells treated with control media caused a small increase in bone resorbing activity; however, when $17 \beta$-estradiol was added to the MCF-7 cells in concentrations of $1 \mathrm{nM}$, bone resorbing activity increased $100 \%$ (Fig. 1). Maximal effects were seen at $1 \mathrm{nM}$, although some effect was also seen at $10 \mathrm{nM}$. The dose response curve for $17 \beta$-estradiol showed a biphasic response with no bone resorbing activity being released at $0.1 \mu \mathrm{M}$ or $0.1 \mathrm{nM}$. In contrast, $17 \alpha$-estradiol caused no release in bone resorbing activity at concentrations of $1 \mathrm{nM}$. There was some increase in the release of bone resorbing activity from MCF-7 cells cultured with $0.1 \mu \mathrm{M} 17 \alpha$-estradiol. There are several possible explanations for this effect of $17 \alpha$-estradiol. The preparation

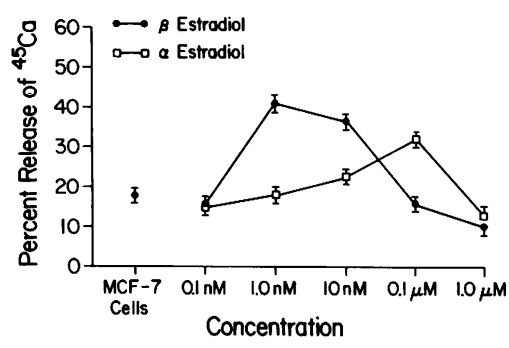

Figure 1 . The effects of $17 \beta$-estradiol and $17 \alpha$-estradiol on the release of bone resorbing activity from MCF-7 cells. Bone resorption was assessed by the release of previously incorporated ${ }^{45} \mathrm{Ca}$ from fetal rat long bones in organ culture, and was expressed as the percent release of ${ }^{45} \mathrm{Ca}$. Control bones cultured with media alone released $9.1 \pm 0.2 \%$ of previously incorporated ${ }^{45} \mathrm{Ca}$. Bones cultured with $17 \alpha$-estradiol $(0.1 \mathrm{nM})$ released $8.9 \pm 0.3 \%$ of total ${ }^{45} \mathrm{Ca}$, and bones cultured with $17 \alpha$-estradiol $(1 \mu \mathrm{M})$ released $8.1 \pm 0.4 \%$ of total ${ }^{45} \mathrm{Ca}$. Bones cultured with $17 \beta$-estradiol $(1 \mathrm{nM})$ released $8.3 \pm 0.4 \%$ of total ${ }^{45} \mathrm{Ca}$, and bones cultured with $17 \beta$-estradiol $(1 \mu \mathrm{M})$ released $7.7 \pm 0.5 \%$ of total ${ }^{45} \mathrm{Ca}$. Results are expressed as means \pm SEM for four pairs of bone cultures. 


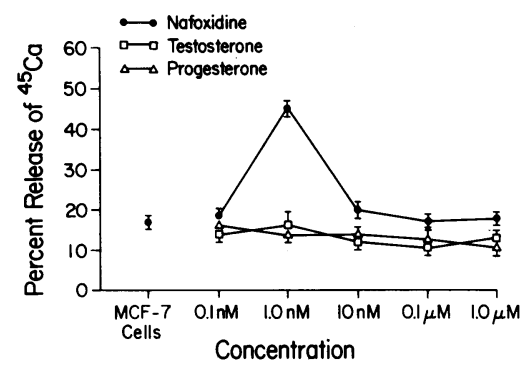

Figure 2. The effects of nafoxidine, testosterone, and progesterone on the release of bone resorbing activity from MCF-7 cells. Bone resorption is expressed as percent release of previously incorporated ${ }^{45} \mathrm{Ca}$ from fetal rat long bones in organ culture. Bones cultured without cells in the presence of control media plus hormones released the following amounts of previously incorporated ${ }^{45} \mathrm{Ca}$ : control media alone, $9.8 \pm 0.3 \%$; nafoxidine $(0.1 \mathrm{nM}), 9.2 \pm 0.4 \%$; nafoxidine $(1 \mu \mathrm{M}), 9.0 \pm 0.5 \%$; testosterone $(0.1 \mathrm{nM}), 10.1 \pm 0.7 \%$; testosterone (1 $\mu \mathrm{M}), 9.2 \pm 0.6 \%$; progesterone $(0.1 \mathrm{nM}), 9.7 \pm 0.5 \%$; and progesterone (1 $\mu \mathrm{M}), 10.5 \pm 0.4 \%$.

of $17 \alpha$-estradiol may have been contaminated with small amounts of $17 \beta$-estradiol which produced this apparent effect at $0.1 \mu \mathrm{M}$. It is also possible that in this sytem $17 \alpha$-estradiol competes for the $17 \beta$-estradiol receptor and causes a partial agonist effect.

Nafoxidine, which binds to the estrogen receptor, also caused the MCF-7 cells to release bone resorbing activity at low concentrations (Fig. 2). However no effects were seen with testosterone and progesterone in the fetal rat long bone system (Fig. 2).

$17 \beta$-Estradiol $(10 \mathrm{nM})$ added to MCF-7 cells also caused release of ${ }^{45} \mathrm{Ca}$ from organ cultures of live mouse calvaria when the estradiol was added $96 \mathrm{~h}$ before the cells were exposed to the bones (Table I). When the cells were cultured with devitalized bone there was no added bone resorbing effect of $17 \beta$-estradiol, although we confirmed our previous data (10) showing a small direct resorption of devitalized bone by breast cancer cells (Table II). $\mathrm{pH}$ was monitored in the medium of the co-culture wells and in the control wells. The lowest $\mathrm{pH}$ we found was 6.4. In a separate experiment (data not shown), ${ }^{45} \mathrm{Ca}$ release induced by lowering $\mathrm{pH}$ from 7.6 to 6.4 was measured. This experiment was conducted during two consecutive 48-h periods on live and on devitalized bones. We found that the effect of estradiol on live bones could not be ascribed to changes in $\mathrm{pH}$ alone because even when the effects of $\mathrm{pH}$ were accounted for, there was still substantial release of ${ }^{45} \mathrm{Ca}$ by $17 \beta$-estradiol. The effects of steroid hormones could not be ascribed to an increase in cell growth. We found no increase in $\left[{ }^{3} \mathrm{H}\right]$ thymidine incorporation by $\mathrm{MCF}-7$ cells exposed to concentrations of 10 or $1 \mathrm{nM} 17 \beta$-estradiol, indicating that the effects we observed were not related to an increase in cell replication (data not shown). In co-culture experiments with mouse calvaria, DNA content of the cancer cells was determined at the end of the co-culture period: it was the same whether the cells were unexposed to steroid hormones, or incubated with dihydrotestosterone or $17 \beta$-estradiol.

To test the specificity of the effect of $17 \beta$-estradiol and nafoxidine on the release of bone resorbing activity by breast cancer cells, we examined MDA-231 cells that do not have estrogen receptors. Release of ${ }^{45} \mathrm{Ca}$ from organ cultures of both mouse calvaria and fetal rat long bones was assessed. There was no release of bone resorbing activity from fetal rat long bones when these cells were incubated with either $17 \beta$ - or $17 \alpha$-estradiol (Fig. 3) or from mouse calvaria (Table I).

To determine the mechanism by which MCF-7 cells were causing fetal rat long bones and mouse calvaria to resorb when exposed to $17 \beta$-estradiol and nafoxidine, we tested the hypothesis that prostaglandin synthesis by the cancer cells may be involved. We determined if MCF-7 cells were releasing prostaglandins of the E series, which are the most potent bone resorbing prostaglandins, in response to the estrogens. To do this, we incubated the cells with indomethacin $(10 \mu \mathrm{M})$ and flufenamic acid $(50 \mathrm{uM})$, two compounds that inhibit cyclooxygenase but that are structurally unrelated. We found that the release of bone resorbing activity by the MCF-7 cells in response to the $17 \beta$-estradiol was associated with a marked increase in $\mathrm{PGE}_{2}$ production by the cells (Table III). Indomethacin and flufenamic acid both inhibited release of bone resorbing activity and of $\mathrm{PGE}_{2}^{\prime}$. This is consistent with the hypothesis that the mechanism by which the MCF-7 cells were causing bone resorption after exposure to $17 \beta$-estradiol was the release of prostaglandins of the E series.

To explore the relationship of bone resorbing activity by

Table I. Effects of Cultured Human Breast Cancer Cells on ${ }^{45}$ Ca Release from Live Neonatal Mouse Calvaria

\begin{tabular}{llllll}
\hline Cells & & & \multicolumn{2}{l}{$\begin{array}{l}\text { Treated/control ratio of }{ }^{45} \mathrm{Ca} \text { release } \\
\text { Duration of bone culture }\end{array}$} \\
\hline & $n$ & $\begin{array}{l}\text { Hormonal addition } \\
\text { to media }\end{array}$ & $\begin{array}{l}\text { Time of exposure } \\
\text { of cells to hormone }\end{array}$ & $0-48 \mathrm{~h}$ & $48-96 \mathrm{~h}$ \\
MCF-7 & 38 & None & $h$ & $0-99 \pm 0.03$ & $1.26 \pm 0.05^{*}$ \\
MCF-7 & 26 & $17 \beta$-estradiol & $0-96$ & $0.98 \pm 0.04$ & $1.27 \pm 0.08^{*}$ \\
MCF-7 & 21 & $17 \beta$-estradiol & -96 to +96 & $1.28 \pm 0.05^{*}$ & $1.49 \pm 0.06^{*}$ \\
MDA-231 & 21 & None & $0-96$ & $1.03 \pm 0.02$ & $1.06 \pm 0.04$ \\
MDA-231 & 17 & $17 \beta$-estradiol & $0-96$ & $0.98 \pm 0.03$ & $1.10 \pm 0.04^{*}$ \\
MDA-231 & 4 & $17 \beta$-estradiol & -96 to +96 & $0.99 \pm 0.14$ & $1.19 \pm 0.14$
\end{tabular}

Results were calculated as ratios of ${ }^{45} \mathrm{Ca}$ release from bones cultured with MCF-7 cells and hormones as indicated compared with bones treated in exactly the same way, except that cells were not added. The details of the technique are given in the Methods section. 17\%-Estradiol was added in a concentration of $10 \mathrm{nM}$. The percent release of total ${ }^{45} \mathrm{Ca}$ from bones treated with control media alone over the first $48 \mathrm{~h}$ was $19.6 \pm 0.9 \%$ and from $48-96 \mathrm{~h}$ was $10.2 \pm 0.6 \%$. The bones were cultured for a total of $96 \mathrm{~h}$ and the results are expressed as means \pm SEM.

* Significantly $>1.0 ; P<0.001$. 
Table II. Effects of Cultured Human Breast Cancer Cells on ${ }^{45}$ Ca Release from Devitalized Neonatal Mouse Calvaria

\begin{tabular}{|c|c|c|c|c|c|}
\hline \multirow[b]{3}{*}{ Cells } & \multirow[b]{3}{*}{$n$} & \multirow{3}{*}{$\begin{array}{l}\text { Hormonal addition } \\
\text { to media }\end{array}$} & \multirow{3}{*}{$\begin{array}{l}\text { Time of exposure } \\
\text { of cells to hormone }\end{array}$} & \multicolumn{2}{|c|}{ Treated/control ratio of ${ }^{45} \mathrm{Ca}$ release } \\
\hline & & & & \multicolumn{2}{|c|}{ Duration of bone culture } \\
\hline & & & & $0-48 \cdot h$ & $48-96 \mathrm{~h}$ \\
\hline & & & $h$ & & \\
\hline MCF-7 & 32 & - & $0-96$ & $1.10 \pm 0.02^{*}$ & $1.09 \pm 0.02^{*}$ \\
\hline MCF-7 & 22 & $17 \beta$-estradiol & $0-96$ & $1.10 \pm 0.03^{*}$ & $1.09 \pm 0.02^{*}$ \\
\hline MCF-7 & 6 & $17 \beta$-estradiol & -96 to +96 & $0.99 \pm 0.13$ & $1.01 \pm 0.06$ \\
\hline
\end{tabular}

Results were calculated as ratios of ${ }^{45} \mathrm{Ca}$ release from bones cultured with MCF-7 cells and hormones as indicated compared with bones treated in exactly the same way, except that cells were not added. The details of the technique are given in the Methods section. 17 $\beta$-Estradiol was added in a concentration of $10 \mathrm{nM}$. The percent release of total ${ }^{45} \mathrm{Ca}$ for bones treated with control media above over the first $48 \mathrm{~h}$ was $8.2 \pm 0.2 \%$ and from $48-96 \mathrm{~h}$ was $4.6 \pm 0.1 \%$. The bones were cultured for a total of $96 \mathrm{~h}$ and the results are expressed as means \pm SEM.

* Significantly $>1.0 ; P<0.001$.

MCF-7 cells to prostaglandin production further, we performed dose response curves with $17 \beta$-estradiol, $17 \alpha$-estradiol, and nafoxidine on the release of $\mathrm{PGE}_{2}$ by cultured MCF-7 cells. We found the maximal increase of prostaglandins of the $E$ series by the effects of $17 \beta$-estradiol and nafoxidine occurred at concentrations of $1 \mathrm{nM}$ (Fig. 4), coinciding perfectly with the release of bone resorbing activity (Figs. 1 and 2). 17 $\alpha$ Estradiol caused a small increase in $\mathrm{PGE}_{2}$ release at concentrations of $0.1 \mu \mathrm{M}$, again coinciding perfectly with the release of bone resorbing activity by MCF-7 cells at the same concentration (Fig. 1). These findings are again consistent with the notion that the mechanism by which the MCF-7 cells cause bone resorption when incubated with $17 \beta$-estradiol or nafoxidine is prostaglandin release.

\section{Discussion}

The data in this paper indicate that cultured human breast cancer cells in vitro can release bone resorbing activity and prostaglandins upon acute exposure to $17 \beta$-estradiol as well as to nonsteroidal compounds that compete with $17 \beta$-estradiol for the estrogen receptor. The data are consistent with the hypothesis that these breast cancer cells release prostaglandins in response to $17 \beta$-estradiol, and that the prostaglandins are at least in part responsible for the increase in bone resorption. These laboratory observations may explain why some patients

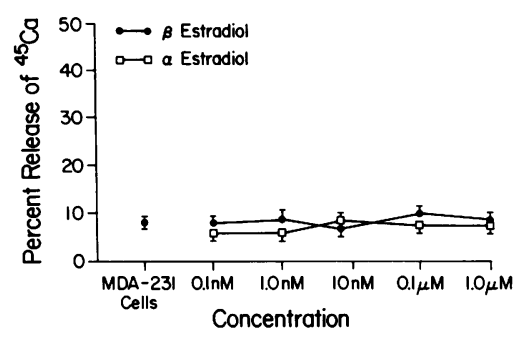

Figure 3. The effects of $17 \beta$-estradiol and $17 \alpha$-estradiol on the release of bone resorbing activity from MDA-231 cells (which do not have estrogen receptors). Bone resorbing activity is expressed as the percent release of previously incorporated ${ }^{45} \mathrm{Ca}$ from fetal rat long bones in organ culture. Bones cultured without cells in the presence of control media plus hormones released the following amounts of previously incorporated ${ }^{45} \mathrm{Ca}$ : control media alone, $8.8 \pm 0.2 \% ; 17 \alpha$ estradiol $(0.1 \mathrm{nM}), 8.8 \pm 0.6 \% ; 17 \alpha$-estradiol $(1 \mu \mathrm{M}), 7.9 \pm 0.7 \% ; 17 \beta$ estradiol $(0.1 \mathrm{nM}), 9.2 \pm 0.4 \%$; and $17 \beta$-estradiol $(1 \mu \mathrm{M}), 10.6 \pm 0.7 \%$. with advanced breast cancer develop acute hypercalcemia when treated with estrogens or antiestrogens, and why bone lesions appear to be more prominent in patients with estrogen receptor positive tumors.

The mechanisms of bone resorption in patients with advanced breast cancer may be complex and multifactored. Recently, we have shown that breast cancer cells themselves have the direct capacity to resorb bone independent of osteoclasts (10). The direct effect of tumor cells may be related to collagenolytic factors secreted by the malignant cells $(10,11)$. It has been shown that MCF-7 cells produce collagenolytic and lysosomal enzymes $(10,11)$. Using cultures of mammary tumor explants, Heuson et al. (28) have shown that scirrhous tumors survive less well in serum free medium than tumors with loose connective stroma. Supplementation of the medium with $17 \beta$-estradiol $(0.1-10 \mathrm{ng} / \mathrm{ml})$ did not affect nonscirrhous tumors but markedly improved the survival of scirrhous tumor cancer cells throughout the explant. This improvement was

Table III. Effect of Inhibitors of Prostaglandin Synthesis on Release of Bone Resorbing Activity, Assessed Using Fetal Rat Long Bones, and PGE from MCF-7 Cells in Response to 17R-Estradiol (1 nM)

\begin{tabular}{|c|c|c|c|}
\hline $\begin{array}{l}\text { MCF-7 cells } \\
\text { treated with }\end{array}$ & $\begin{array}{l}\text { Bone resorbing activity } \\
\text { (percent release } \\
\text { of }{ }^{45} \mathrm{Ca} \text { ) }\end{array}$ & $\mathrm{PGE}_{2}$ & $\begin{array}{l}\text { Cell } \\
\text { protein }\end{array}$ \\
\hline & & $\begin{array}{l}\mathrm{pg} / \mathrm{mg} \text { protein } \\
\text { per } h\end{array}$ & $m g$ \\
\hline Control media & $18.1 \pm 0.4$ & $6.1 \pm 0.4$ & $0.48 \pm 0.02$ \\
\hline $17 \beta$-estradiol & $38.9 \pm 1.2^{*}$ & $52.3 \pm 2.8^{*}$ & $0.52 \pm 0.03$ \\
\hline \multicolumn{3}{|l|}{$17 \beta$-estradiol } & \\
\hline$(0.1 \mu \mathrm{M})$ & $10.3 \pm 0.5$ & $3.2 \pm 0.1$ & $0.54 \pm 0.02$ \\
\hline \multicolumn{4}{|l|}{$\begin{array}{l}\text { 17 } \beta \text {-estradiol } \\
+ \text { flufenamic a }\end{array}$} \\
\hline$(0.5 \mu \mathrm{M})$ & $12.9 \pm 0.9$ & $3.9 \pm 0.2$ & $0.56 \pm 0.03$ \\
\hline \multicolumn{4}{|l|}{ Indomethacin } \\
\hline$(0.1 \mu \mathrm{M})$ & $11.7 \pm 0.8$ & $4.3 \pm 0.3$ & $0.49 \pm 0.02$ \\
\hline \multicolumn{4}{|l|}{ Flufenamic acid } \\
\hline$(0.5 \mu \mathrm{M})$ & $10.9 \pm 0.7$ & $5.2 \pm 0.2$ & $0.43 \pm 0.02$ \\
\hline
\end{tabular}

Bones treated with media containing $17 \beta$-estradiol $(1 \mathrm{nM})$ released $9.1 \pm 0.2 \%$ of total ${ }^{45} \mathrm{Ca}$; bones treated with media containing indomethacin $(0.1 \mu \mathrm{M})$ released $11.1 \pm 0.3 \%$ of total ${ }^{45} \mathrm{Ca}$; bones treated with media containing flufenamic acid $(0.5 \mu \mathrm{M})$ released $9.9 \pm 0.5 \%$ of total ${ }^{45} \mathrm{Ca}$. * Significantly greater than cells treated with control media; $P<0.05$. 


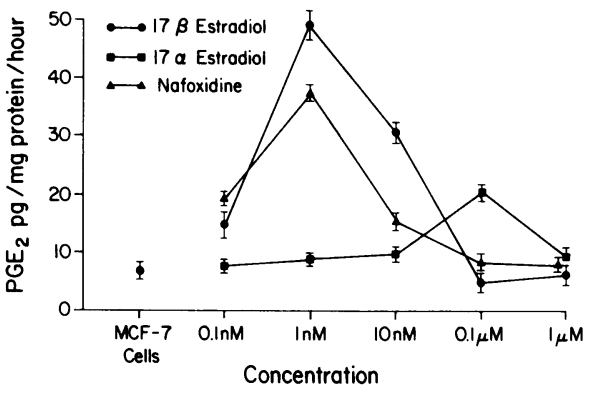

Figure 4. The effects of $17 \beta$-estradiol, $17 \alpha$-estradiol, and nafoxidine on the release of $\mathrm{PGE}_{2}$ from cultured MCF-7 cells under the same conditions as shown in Figs. 1 and 2.

associated with collagen digestion around the neoplastic cells. More information is required to determine the relationship between estrogen responsiveness and the release of collagenolytic activity by breast cancer cells.

Others have suggested that osteoclasts are important in the bone resorption that occurs in metastatic bone disease (8). It is possible that osteoclasts present at the bone margins mediate bone destruction after activation by prostaglandins produced by the tumor cells or by monocytes that accumulate as part of the cell-mediated response to the tumor. The lymphokine osteoclast activating factor $(29,30)$ could also activate osteoclasts at metastatic sites as part of the cellular immune response to the presence of the tumor. From the observations we have described here, we suggest that on exposure to estrogens or compounds that bind to estrogen receptors, some breast cancer cells may release factors that cause osteoclast activation.

Although our data are consistent with prostaglandin production by the breast cancer cells mediating the effects we observed, we cannot exclude another bone resorbing factor in addition to prostaglandin $\mathrm{E}$ being produced by the tumor cells. Prostaglandins $\mathrm{E}$ in the concentration range of $100-500$ $\mathrm{pg} / \mathrm{ml}$ may stimulate bone resorption $(31,32)$, but not usually to the extent seen here. However, indomethacin and flufenamic acid are structurally unrelated drugs that inhibit prostaglandin synthesis, and their ability to inhibit production of all of the bone resorbing activity by the MCF-7 cells suggests that prostaglandins are responsible at least in part for the bone resorbing activity (Table III).

Our results support previous studies showing that some breast tumors can produce more prostaglandins than others (33). These tumors may spread more easily, show higher osteolytic activity in vitro (34), and may be associated more frequently with bone metastases (33). Taken together with our results, these observations may suggest that estrogen receptor positive breast tumors have a higher osteolytic activity and spread more easily to bone. This assumption is supported by clinical observers who have noted that there are differences in patterns of metastasis of estrogen receptor positive and estrogen receptor negative breast cancers. Estrogen receptor positive tumors metastasize earlier to bone, while estrogen receptor negative tumors metastasize to viscera (35-38).

The changes we observed cannot be ascribed either to changes in $\mathrm{pH}$ or simply to alterations in cell proliferation in response to estrogens. We cultured fetal rat long bones with media harvested from MCF-7 cells that were readjusted to $\mathrm{pH}$ 7.34 before incubation with the bones. When co-culture of the
MCF-7 cells with the neonatal mouse calvaria was performed, the $\mathrm{pH}$ fell. However, in separate experiments we assessed the bone resorption caused by similar changes in $\mathrm{pH}$ and found that increased release of previously incorporated ${ }^{45} \mathrm{Ca}$ from neonatal mouse calvaria due to identical changes in $\mathrm{pH}$ could not account for the marked increase in ${ }^{45} \mathrm{Ca}$ release from cells co-cultured with the bones. When bones were cultured with dihydrotestosterone at $0.1 \mu \mathrm{M}$, there was increased release of ${ }^{45} \mathrm{Ca}$ from the calvaria. However, we found there was also increased production of acid by these cultured cells and increased release of ${ }^{45} \mathrm{Ca}$ could be ascribed to acid production. In contrast, although $17 \beta$-estradiol also increased acid production by MCF-7 cells, the release of ${ }^{45} \mathrm{Ca}$ was greater and could not be ascribed to the $\mathrm{pH}$ effect. The increased bone resorbing activity by cells cultured with $17 \beta$-estradiol could also not be ascribed simply to increased cell proliferation or DNA synthesis. In separate experiments, we measured DNA content of the cultured cells and $\left[{ }^{3} \mathrm{H}\right]$ thymidine incorporation. Under the conditions of these experiments, there was neither an increase in DNA content nor in $\left[{ }^{3} \mathrm{H}\right]$ thymidine incorporation. These results indicate that on exposure to $17 \beta$-estradiol or nafoxidine, there was increased release of bone resorbing activity by the MCF-7 cells without a parallel change in cell replication.

The clinical importance of estrogen-induced hypercalcemia has become less significant since estrogens are now used rarely as single agents in the treatment of advanced breast cancer. However, tamoxifen or nafoxidine are commonly used, and a small number of women with advanced breast cancer develop acute hypercalcemia when treated with these agents (18). Occasionally, this type of hypercalcemia develops very rapidly and may be irreversible (17). This may occur even when the drug causes a decrease in tumor cell growth (18), so that in tamoxifen-treated patients it is important to avoid life-threatening transient hypercalcemia. If, in fact, the mechanism of acute increases in bone resorption and hypercalcemia in some patients with metastatic breast cancer treated with estrogens or antiestrogens is by the release of prostaglandins by the tumor cells, then it is possible to avoid this complication by prophylactic therapy with agents that decrease prostaglandin synthesis, such as indomethacin. Clinical studies may be warranted to determine if patients with advanced breast cancer who are treated with estrogens or antiestrogens as part of their routine care will develop an acute increase in bone resorption that can be inhibited by blockade of prostaglandin synthesis.

\section{Acknowledgments}

This work was supported in part by grants CA-29537 and AM-28149 from the National Institutes of Health, and by grant 910-00R of the Unité Enseignement Recherchre de Biologie Humaine-Université Lyon 1.

\section{References}

1. Mundy, G. R., and T. J. Martin. 1982. Hypercalcemia of malignancy. Pathogenesis and treatment. Metabolism. 31:1247-1277.

2. Skarloff, D. M., and N. D. Charkes. 1968. Bone metastases from breast cancer at the time of radical mastectomy. Surg. Gynecol. Obstet. 127:763-768.

3. Galasko, C. S. B. 1969. The detection of skeletal metastases from mammary cancer by gamma camera scintigraphy. Br. J. Surg. 56:757-764.

4. Hoffman, H. C., and R. Marty. 1972. Bone scanning: its value 
in the preoperative evaluation of patients with suspicious breast masses. Am. J. Surg. 124:194-199.

5. Galasko, C. S. B., and J. I. Burn. 1971. Hypercalcemia in patients with advanced mammary cancer. Br. Med. J. 3:573-577.

6. Powles, T. J., S. A. Clark, D. M. Easty, G. C. Easty, and A. M. Neville. 1973. The inhibition by aspirin and indomethacin of osteolytic tumor deposits and hypercalcemia in rats with Walker tumour, and its possible application to human breast cancer. Br. J. Cancer. 28:316321.

7. Powles, T. J., M. Dowsett, G. C. Easty, D. M. Easty, and A. M. Neville. 1976. Breast-cancer osteolysis, bone metastases, and antiosteolytic effect of aspirin. Lancet. I:608-613.

8. Galasko, C. S. B. 1976. Mechanisms of bone destruction in the development of skeletal metastases. Nature (Lond.). 263:507-508.

9. Greaves, M., K. J. Ibbotson, D. Atkins, and T. J. Martin. 1980. Prostaglandin as mediators of bone resorption in renal and breast tumors. Clin. Sci. (Lond.). 58:201-210.

10. Eilon, G., and G. R. Mundy. 1978. Direct resorption of bone by human breast cancer cells in vitro. Nature (Lond.). 276:726-728.

11. Eilon, G., and G. R. Mundy. 1981. Effects of inhibition of microtubule assembly on bone mineral release and enzyme release by human breast cancer cells. J. Clin. Invest. 67:69-76.

12. Horwitz, K. B., D. T. Zava, A. K. Thilagar, E. M. Jensen, and W. L. McGuire. 1975. Steroid receptor analyses of nine human breast cancer lines. Cancer Res. 38:2434-2437.

13. Ciocca, D. R., D. J. Adams, D. P. Edwards, R. J. Eyerke, and W. L. McGuire. 1983. Distribution of an estrogen induced protein with a molecular weight of 24,000 in normal and malignant human tissues and cells. Cancer Res. 43:1204-1210.

14. Jozan, S., B. Kreitmann, and F. Bayard. 1981. Different effects of oestradiol, oestriol and oestrone on human breast cancer cells. Acta Endocrinol. 98:73-80.

15. Herman, J. B., E. Kirsten, and J. S. Krakauer. 1949. Hypercalcemic syndrome associated with androgenic and estrogenic therapy. J. Clin. Endocrinol. 9:1-12.

16. Kennedy, B. J., D. M. Tibbetts, I. T. Nathanson, and J. C. Aub. 1953. Hypercalcemia, a complication of hormone therapy of advanced breast cancer. Cancer Res. 13:445-459.

17. Cornbleet, M., P. K. Bondy, and T. J. Powles. 1977. Fatal irreversible hypercalcemia in breast cancer. Br. Med. J. 1:145.

18. Spooner, D., and B. D. Evans. 1979. Tamoxifen and lifethreatening hypercalcemia. Lancet. II:413-414.

19. Hall, T. C., M. M. Dederick, and H. B. Nevinny. 1963. Prognostic value of hormonally induced hypercalcemia in breast cancer. Cancer Chemother. Rep. 30:21-23.

20. Patterson, J. S., and M. Baum. 1978. Safety of tamoxifen. Lancet. I: 105.

21. Raisz, L. G. 1965. Bone resorption in tissue culture. Factors influencing the response to parathyroid hormone. J. Clin. Invest. 44: 103-116.

22. Trummel, C. L., G. R. Mundy, and L. G. Raisz. 1975. Release of osteoclast activating factor by normal human peripheral blood leukocytes. J. Lab. Clin. Med. 85:1001-1007.
23. Soule, H. D., J. Vazquez, A. Long, S. Albert, and M. Brennan. 1973. A human cell line from a pleural effusion derived from a breast carcinoma. J. Natl. Cancer Inst. 51:1409-1416.

24. Cailleau, R., R. Young, M. Olive, and W. J. Reeves, Jr. 1974. Breast tumor cell lines from pleural effusions. J. Natl. Cancer Inst. 53: 661-674.

25. Reynolds, J. J. 1966. The effect of ascorbic acid on the growth of chick bone rudiments in chemically defined medium. Exp. Cell. Res. 42:178-188.

26. Lowry, L. H., N. J. Rosenbrough, A. L. Farr, and R. J. Randall. 1951. Protein measurement with the folin phenol reagent. J. Biol. Chem. 193:265-275.

27. Karsten, V., and A. Wollenberger. 1977. Improvement in the ethidium bromide method for direct fluorometric estimation of DNA and RNA in cells and tissue homogenates. Anal. Biochem. 77:464470.

28. Heuson, J. C., J. L. Pasteels, N. Legros, J. Heuson-Stiennon, and G. Leclerq. 1975. Estradiol dependent collagenolytic enzyme activity in long-term organ culture of human breast cancer. Cancer Res. 35:2039-2048.

29. Horton, J. E., L. G. Raisz, H. A. Simmons, J. J. Oppenheim, and S. E. Mergenhagen. 1972. Bone resorbing activity in supernatent fluid from cultured human peripheral blood leukocytes. Science (Wash. DC). 177:793-795.

30. Raisz, L. G., R. A. Luben, G. R. Mundy, J. W. Dietrich, J. E. Horton, and C. L. Trummel. 1975. Effect of osteoclast activating factor from human leukocytes on bone metabolism. J. Clin. Invest. 56:408413.

31. Klein, D. C., and L. G. Raisz. 1970. Prostaglandins: stimulation of bone resorption in tissue culture. Endocrinology. 86:1436-1440.

32. Mundy, G. R., R. A. Luben, L. G. Raisz, J. J. Oppenheim, and D. N. Buell. 1974. Bone-resorbing activity in supernatants from lymphoid cell lines. $N$. Engl. J. Med. 290:867-871.

33. Bennett, A., A. M. McDonald, I. F. Stamford, E. M. Charlier, J. S. Simson, and O. Zebro. 1977. Prostaglandins and breast cancer. Lancet. II:624-626.

34. Greaves, M., K. J. Ibbotson, D. Atkins, and T. J. Martin. 1980. Prostaglandins as mediators of bone resorption in renal and breast tumors. Clin. Sci. (Lond.). 58:201-210.

35. Singhakowinta, A., D. W. Saunders, S. C. Brooks, B. Samal, and V. K. Vaitkevicius. 1980. Clinical application of estrogen receptor in breast cancer. Cancer. 46:2932-2938.

36. Campbell, F. C., R. W. Blamey, C. W. Elston, R. I. Nicholson, K. Griffiths, and J. L. Haybittle. 1981. Oestrogen receptor status and sites of metastasis in breast cancer. Br. J. Cancer. 44:456-459.

37. Samaan, N. A., A. U. Buzdar, K. A. Aldinger, P. N. Schultz, K. P. Yang, M. M. Romsdaml, and R. Martin. 1981. Estrogen receptor: a prognostic factor in breast cancer. Cancer. 47:554-560.

38. Stewart, J. F., R. J. B. King, S. A. Sexton, R. R. Millis, R. D. Rubens, and J. L. Hayward. 1981. Oestrogen receptors, sites of metastatic disease and survival in recurrent breast cancer. Eur. $J$. Cancer. 17:449-453. 